\title{
Özbek Ceditçi Hamza Hakimzoda Niyoziy'nin Tiyatro Faaliyetleri ve Zaharli Hayot Yohud Ishk Qurbonları (Zehirli Hayat Yahut Aşk Kurbanları) Piyesi
}

\author{
Uzbek Jadıdıst Hamza Hakımzoda Niyozıy's Theatre Actıvitıes and Play of \\ Zaharli Hayot Yohud Ishk Qurbonları (Zehirli Hayat Yahut Aşs \\ Kurbanları) \\ Tugba BÍLVEREN ${ }^{*}$
}

$\ddot{O} \mathbf{z}$

Cedit tiyatrosunun amacı, siyasi ve sosyal hadiselerin yansıtılması, eğitimli ve aydın olma düşüncelerinin, hürriyet bilincinin halka kolay ulaştırılması olmuştur. Halktan büyük ilgi ve takdir gören cedit tiyatrosu, eğitimde yenileşmeyi temel almış, karşılaşılan tüm olumsuzlukların aslında eğitimsizlikten ve cahillikten kaynaklandığını vurgulamıştır. İşgal ve sömürgeden kurtulmanın çaresi olarak yenileşmenin şart olduğunu savunan Ceditçiler, genç nesillerin modern yöntemlerle eğitilmelerinde 1srarcı olmuşlardır. 20.yy'ın ilk yıllarında Özbek milli tiyatrosunun meydana gelmesinde ve aydınlanma hareketinin oluşmasında en büyük pay ceditçi aydınlarındır. Çağdaş medeniyet seviyesine yükselmenin halkı bilinçlendirmeyle olacağını ve bunun için en kestirme ve etkili yolun tiyatro olduğunu düşünen ceditçilerin en önemli temsilcilerinden biri de Hamza Hakimzoda Niyoziy'dir. Özbek edebiyatına büyük katkıları olan Hamza Hakimzoda Niyoziy, iyi bir eğitimci, iyi bir şair ve önemli bir tiyatro yazarıdır. Kırktan fazla sahne eseri bulunan Hamza Hakimzoda Niyoziy'nin hayatı ve eserleri pek çok çalışmaya konu olmuş, Özbekistan Devlet Sanatçısı unvanıyla ödüllendirilmiştir. Pek çok devlet kurumuna adı verilmiş olan Hamza Hakimzoda'nin çalş̧mamıza konu olan Zaharli Hayot Yohud Ishk Qurbonlari isimli piyesi insan hayatına kast edecek seviyelerdeki geri kalmışlı̆ı̆n doğurduğu sonuçları, eğitilmemiş ailelerin sebebiyet vereceği çarpık durumları işlemiştir. Özellikle gençlerin eğitilmesine önem veren Hamza Hakimzoda, Özbeklerin bu bağlamda manevi destekçisi olmuştur. Çalışmamızda yazarın biyografisinin yanı sıra Zaharli Hayot Yohud Ishk Qurbonlari (Zehirli Hayat Yahut Aşk Kurbanları) piyesinin çevirisine yer verilecektir.

Anahtar Kelimeler: Tiyatro, Ceditçiler, Hamza Hakimzoda, Piyes.

\begin{abstract}
The aim of the Jadid theater was to reflect political and social events, to educate and enlightened thoughts and to bring freedom of consciousness to the public easily. The Jadid theater, which has received great interest and appreciation from the public, is based on innovation in education and emphasizes that all the problems encountered are in fact caused by lack of education and ignorance. Jadidists, defending the necessity of modernization as a cure for invasion and colonial liberation, insisted on educating the younger generations with modern methods. In the first years of the 20th century, the Jadidist intellectuals had the biggest share in the formation of the Uzbek national theater and the formation of the enlightenment movement. Hamza Hakimzoda Niyoziy is one of the most important representatives of the Ceditists who think that the rise to the level of contemporary civilization will be through public awareness and the most direct and effective way to do so is theater. He is a great educator, a good poet and an important theater writer. With more than 40 scenes, Hamza's life and works have been the subject of many works and he was awarded the title of State Artist of Uzbekistan. Hamza Hakimzoda, who has been named in many places, is the subject of our study, Zaharli Hayot Yohud Ishk Qurbonlari, has processed the consequences of backwardness at levels that would mean human life, and the distorted situations that would be caused by uneducated families. Hamza Hakimzoda, who attaches importance to the education of young people, has been the spiritual supporter of the Uzbeks in this context. In addition to the biography of the author, Zaharli Hayot Yahud Ishk Qurbanlari (Poisoned Life Or Love Victims) will be included in our study.
\end{abstract}

Key Words: Theatre, Jadidists, Hamza Hakimzoda, Play.

\section{Giriş}

1900-1930 yıllarında çarlığın yıkılması, özerkliğin kazanılması ve ceditçiliğin gelişmesi Özbek milli tarihinin önemli bir bölümünü temsil eder. 20.yy’ın ilk çeyreğinde Rus baskısı altında üç kez sosyal darbe meydana gelmiş, zulüm ve baskıya karşı üst üste ayaklanmalar başlamıştır. 1898 yılında Dukchi Eshon rehberliğinde Andican'da başlayan

\footnotetext{
*Dr.Öğr.Üyesi, Kilis 7 Aralık Üniversitesi, Fen Edebiyat Fakültesi, tyumrutas@ hotmail.com.
}

Bilveren, T. (2020). Özbek Ceditçi Hamza Hakimzoda Niyoziy’nin Tiyatro Faaliyetleri Ve Zaharli Hayot Yohud Ishk Qurbonları (Zehirli Hayat Yahut Aşk Kurbanları) Piyesi, Asia Minor Studies, Cilt 8 Sayı 1, 418-432, Gönderim tarihi: 12-11-2019, Kabul tarihi: 29-01-2020.

Araştırma Makalesi. 
darbe 1916 yılında Jizzax'da devam etmiş ve tüm yurda yayılmıştır. Bu mücadele sömürgecilerin zulmüne ve adaletsiz siyasete karşı başlatılan milli bir bağımsızlık mücadelesidir. Hatta eldeki kayıtlara göre 130 yıllık sömürge süresince Türkistan'da baskıya karş1 4500 kez büyük küçük isyanlar, ayaklanmalar ve protestolar meydana gelmiştir. Halkın içinden yetişen Mahmud Hoca Behbudiy, Hamza Hakimzoda Niyoziy, Abdurrauf Fitrat gibi dönemin öncü aydınları memleketin içinde bulunduğu durumdan dolayı üzüntü duymaya ve çareler aramaya başlamışlardır. Tüm bu işkence ve eziyet çekmelerin asıl sebebinin bilgisizlik olduğunu savunarak halkı bilinçlendirmenin yollarını aramışlardır. Böylelikle 20.yy'ın başlarında milli uyanışa davet eden ceditçilik hareketi ortaya çıkmıştır. Bu hareketin asıl maksadı halkın daha bilinçli ve memleketin daha kalkınmış olmasını sağlamaktır (Mirzayev, 2005: 9-10).

Toplumu derinden etkileyen cedit hareketi, cemiyetin ıslahını ve terbiyesini hedef alarak sosyo-politik anlamda ve kültürel bakımdan yenilenme çabasıdır. Karakaş, Türkistan'da çeşitli politikaların hayata geçirilmesi amacıyla Türkçenin geri plana atılması ve diyalektolojiye önem verilmesi, okulların kontrol altına alınması, çeşitli dergi ve gazete yayınları ile bu faaliyetlerin desteklenmesini Ruslaştırma programı dâhilinde yapıldığını belirtir. Asıl amaç mahalli kültürün yıkılmasıdır. Seyirciye çabuk ulaşması bakımından önem taşıyan sahne çalışmaları amacın gerçekleştirilmesinde büyük önem taşır. Bu sebeple birçok Rus topluluk pek çok şehirde eserler sahneye koyar. Bu durum milli bir tiyatronun doğmasına da zemin hazırlamıştır. Bu bağlamda tiyatro sanatı, modern eğitimin yaygınlaşması, siyasi ve sosyal faaliyetlerin artırılması için de önemli bir vasıta olacaktır. Bu düşünceyi hayata geçirenler ise ceditçi aydınlardır (Karakaş, 2001, s.164,165). 20.yy'ın ilk yılları yeni Özbek milli tiyatrosunun meydana geldiği yıllardır. Halkı ilim irfan ile uyandırmak isteyen, özgürlük ve yükselişi arzulayan ceditçi aydınlar, bu yoldaki en önemli faaliyetin tiyatro olduğunu düşünmüşlerdir (Rizayev, 1997: 51).

Merkezî Asya'da tiyatro sanatının yükselişi "Maskarabazlık ve Kızıkçılık” sanatıyla birlikte türlü biçimlerde günümüze kadar gelmiştir. Cedit edebiyatında drama türünde eserler yazılıncaya kadar maskarabaz ve klzıkçı tiyatrosu sözlü olarak devam etmiştir (Rizayev, 1997: 14). O dönemlerde Zokir Eshon, Rızo Qıyıq, Sa'id Mahsum, Usmon Qızıq, Ruzi Gov, Shomat Qızıq, Davlat Qızıq, Mizrom Mashara, To'la Mashara, Quvvat Kalta, Boltaqul, Matyoqub gibi Kaşgar vilayetinde ün kazanmış onlarca temsilci yetişmiştir (Rizayev, 1997: 18). Kızıkçılık ve maskarabazlık aynı anlama gelecek biçimde kullanılsa da aslında farklıdır. Baydemir, kızıkçıların hikâye anlatan, şarkı söyleyen, dans eden ve şaka yaparak insanları güldüren ancak maskarabazların sıra dışı giyinen ve ikişer üçer gruplar halinde gezen, düğünlerde ve bayramlarda gösteriler düzenleyen kişiler olduğunu belirtir. Usta çırak ilişkisine dayanan bu geleneğin diğer zanaat grupları gibi pirleri olduğunu ve dini temeller üzerine kurulduğunu ifade eder (Baydemir, 2011: 764,765).

Rizayev, Rahmonov'un geleneksel Özbek tiyatrosunu iki tema etrafında topladığını belirtir. Ona göre geleneksel piyesler hem insana has mizah ve komediler içeren, hem de güçlü sosyal mesajlar veren satirik piyeslerdir. Ancak Rizayev, geleneksel tiyatro yani maskarabazlığın bilinçli olarak sosyal konulara eğilmediğini dahası modern Özbek tiyatrosundan bazı noktalarda ayrıldığını ve bu görüşe kısmen katılmadığını belirtir. Geleneksel tiyatroda ilk amacin k1lıktan k1lığa girerek güldürme ve eğlendirme olduğunu, mevcut sorunları ifşa etme maksadıyla sosyal bir tip yaratma kaygısının olmadığını belirterek bu noktada Cedit tiyatrosundan ayrıldığını ifade eder (1997: 19).

Özbek tiyatro sanatının yükselişinde önemli bir yeri olan Hokand şehrinde, tiyatro faaliyetlerinin ne zaman ve nasıl başladığı konusu dönemin önemli dergilerinden "Oyina" dergisinde izah edilir. Bütün Türkistan şehirlerinde olduğu gibi Hokand'da da milli tiyatro sanatını yaratma isteği "Pederkuş" piyesinin sahnelenmesinden sonra daha da artmıştır. Milli 
tiyatro yaratma hareketinin en önemli temilcisi Hamza Hakimzoda Niyoziy'dir (Rizayev, 1997:71,72).

Hamza Niyoziy oğlu Hakimzoda aslen Darvozlu olup 1889 yılında Hokand şehrinde doğmuştur. Eski tip okul ve medreselerde okumuş, kendi gayretiyle bilgi ve görgüsünü artırmıştır. Şarkî Kıtay’a giderek gazetecilikle uğraşmış, 1905 yılından itibaren şiir yazmaya başlamıştır. "Hakikat ne?” isimli güçlü bir eser yazmış olsa da basılmadığı için kaybolmuştur. 1910 yıllarında Hokand'a yeni bir okul açıp çocukların eğitimiyle ilgilenmiş, kimi zaman hayatın içinden seçtiği konularla birkaç küçük roman yazmıştır. 1911 yılında Türkiye, Afganistan ve Hindistan'a seyahat ederek başka ülkelerdeki ilmi akımlar ve sosyal hayatlarla tanışmıştır. 1915-18 yılları arasında Margilon ve Hokand'da öğretmenlik yapmış, o vakitler Hokand'da bazı gençler tarafından "Gayret" isimli bir kütüphanenin kurulmasına vesile olmuş ve bu yolla Türk-Tatar kitapları toplanmıştır. 1918-19 yıllarında Fergana'da bir tiyatro grubu kurmuş, birkaç milli müzisyen ile kızıl cephede çalışmıştır ${ }^{1}$.

Hamza Hakimzoda Niyoziy’nin yaptığı çalışmalar hem Özbek hem de Kazak, Kırgız, Azeri, Türkmen, Tacik, Uygur, Tatar ve Karakalpak edebiyatlarının gelişmesine de yardım etmiştir. Ünlü Azeri ediplerden Mirza İbrahimov, Hamza Hakimzoda Niyoziy'nın üstün yeteneğinin, vatandaşlık ideallerinin, estetik anlayışının temizliği ve kendine haslığ karşısında saygıyla eğilirim demiştir (Mirzayev, 2005: 120).

Hamza Hakimzoda Niyoziy'nin Özbek edebiyatına edebi ve medeni anlamda büyük bir miras olan eserlerinde içerik zengin ve çerçeve geniştir. Eserleri ve hayatı 1920'li yıllardan itibaren incelenip hakkında bilgi verilen Hamza Hakimzoda Niyoziy'nin, hayatının ve eserlerinin geniş çaplı tanıtımının yapıldığı ilk çalışma Yusuf Sulton'ın Hamza Hakimzoda isimli çalışmasıdır. İkinci dünya savaşından sonra eserlerinde daha çok halkçılık, çağdaşlık ve geleneksellik üzerinde duran Hamza'yı Ibrahim Mo'minov, Komil Yashin, Izzat Sulton, Yusuf Sulton, Vohid Zohidov gibi edipler de öncü kabul etmişlerdir. Bu dönemde Hamza Hakimzoda Niyoziy ile ilgili biyografiler, monografiler ve iki adet doktora tezi yazılmıştır. Yusuf Sultan'ın "Halk Sanatkar" (1959), M. Rahmonov'un "Hamza ve Özbek Tiyatrosu" (1958), L. Qayumov'un "Hamza Hakkındaki Bilimsel Üçleme”si (1962, 1964, 1971), H. Abdusamatov'un "Geleneksellik ve Yenicilik Problemi” (1974), M. Qo'shjonov'un "Hamza Eserlerinden Seçmeler" (1986) isimli kitaplar ve tüm yazılan makaleler bu devrin ürünüdür. Bu eserlerin tümünde Hamza Hakimzoda Niyoziy'nin sosyal faaliyetleri, felsefi ve siyasi görüşü, gelenek ve yenilik meseleleri üzerinde durulmuştur (Mirzayev, 2005: 121).

Hamza Hakimzoda Niyoziy, Çarlık Rusyasının baskısı altında ezilen, mahalli zulümlere maruz kalan, yoksulluğa ve cahilliğe mahkûm edilen Türkistan'1 uyanışa ve bilime çağırır. "Uyuma Özbek eli, artık yükseliş vaktidir...", "Uyan Türkistan, uyanma vakti geldi" şeklinde hitaplar kullanır. 1911-1915 yıllarında önce Hokand'da sonra Margilonda okul açmış, öğretmenlik yapmıştır. "Okuma kitabı", "Kıraat Kitabı" ve "Yeni Edebiyat" isimli ders kitapları yazmış ve işçi çocuklarını parasız okutmuştur. 20’li yıllarda öne çıkan "Özbek Kadınlarına", "Bugün 8 Mart", "Mübarek", "Tursunoy Mersiyesi” gibi şiirleri de mevcuttur. $\mathrm{Bu}$ şiirlerde hurafet ve cehaleti, eski kafalılığı ve özgürlük düşmanlarını yererek kadın özgürlüğünü vurgulamıştır (Mirzayev, 2005: 125, 126, 128).

Hamza Hakimzoda Niyoziy'nin en önemli vasıflarından biri de şairliğidir. Günümüz Özbek şiirinin önemli temsilcilerindendir. Şiirlerinde en dikkat çeken taraf halkın kullandığ dili şiir dili olarak kullanmasıdır. Atasözlerine, deyimlere sıkça yer vermiş ve Arapça, Farsça sözcük kullanımı yerine halk arasında kullanılan ifadeleri tercih etmiştir (Mirzayev ve Shermuhammedov, 1993: 84). 1913 yılında Afganistan, Hindistan, Türkiye ve Arabistan gibi

\footnotetext{
${ }^{1}$ Hamza Hakimzoda Niyoziy, To 'la Asarlar To 'plami, O'zbekiston CCR, Fan Nashriyeti, Taşkent, 1989, s. 307
} 
ülkelere seyahat eden Hamza Hakimzoda Niyoziy, Rusya'nın güney şehirlerinde de bulunmuştur. Gezdiği memleketlerdeki insanları gördükçe kendi milletinin ne kadar yoksul ve cahil olduğunu fark etmiştir. Bu sebeple 1914-1915 yılları arasında "Oku", "İlim İste", "Âlim Olalım", "Kitap", "Kalem”, "Okul”, "Hikâye”, "Doğru Söz”, "Kaplumbağa ve Çiyan”, "Kumarın Başı", "Çocuğunun Kötü Olmasına Sebep Olan Ananın Cezası" gibi pedogoji şiirleri yazmıştır (Mirzayev, 2005: 124). Ceditçi yazarların milli gayelerini yaymak için en çok kullandıkları edebi tür şiir olmuştur. Özellikle Hamza Hakimzoda Niyoziy'nın Milli Şarkılar Iç̧in Milli Şiirler dergisinde yayınlanan Ak gül, Kızıl gül, Pembe gül, Sarı gül, Yeşil gül, Kokulu gül diye isimlenen şiirleri en güzel örneklerdendir. Bu dönemde milli edebiyatın en derin damarı olan şiirden başka nesir, drama ve sosyopolitik konulu yazılardan da faydalanılmıştır. 1910 yılına kadar Özbek edebiyatında drama türünde eser verilmemiş, 19101917 yılları arasında 40’a yakın sahne eseri yazılmıştır (Mirzayev, 2005: 12).

Drama türünde de önemli eserler veren Hamza Hakimzoda Niyoziy, Özbek tiyatroculuğunda başı çekenlerden biri olarak bilinir. "Zengin ile Hizmetçi", "Ferace Sırlarından Bir Görünüş ya da Şarkıcıların İşi”, "Cihan Sermayesinin Son Günleri”, "Özerklik ya da Bağımsızlık", "Töhmetçilerin Cezası", "Kim Doğru”, "Harezm İnkilabı", Fergana Faciası", "Loşman Faciası", "Baskı Kurbanları", “Taşkent'e Seyahat”, "Seçim Önünden” gibi kırka yakın sahne eseri mevcuttur. Özellikle "Zehirli Hayat", "Molla Nurmuhammed Hocanın Küfür Hatası" gibi piyeslerinde geri kalmışlık ve cahillik sebebiyle zor bir hayatın içine düşmüş olan insanların hayatını etkili bir biçimde yansıtmıştır. Cahil bilgisiz kişilerin zorbalık ve insafsızlığını açığa vurmuştur. Esas olarak eski düzeni, örf adetleri açığa vurmak, milliyetçiliği ve eğitimi öne çıkarmak Hamza Hakimzoda Niyoziy'nin eserlerinin içeriğidir. Zehirli Hayat yahut Aşk Kurbanları dramasında sosyal eşitsizlik, kadınların acınacak halleri açıkça gösterilmiştir. Eserde okumuş zengin çocuk Mahmud ile fakir işçi kızı Maryam birbirlerini severler. Ancak mevcut sosyal düzen ve örf-adetlere göre bu gençler birbirlerine kavuşamazlar. Maryam müftü efendiye yedinci eş olarak nikâhlanır. Ancak böyle bir adaletsizliğe asla razı olmaz ve zehir içip ölür. Mahmud ise sevgilisi olmadan yaşamaktansa ölümü tercih eder. Maryam'ın mezarı üstünde hayatını kaybeder. Dramada cahil din adamlarının vicdansızlığı, insafsızlığı ve kadın haklarının ayaklar altına alındığı açıkça vurgulanır (Mirzayev, 2005: 130).

Hamza Hakimzoda Niyoziy'nin dramalarında bazı sanatsal eksikliklere dikkat çeken Mirzayev, monolog ve diyalogların fazla uzun olmasını, bazı durumlarda olayların yavaş gelişmesini ve bazı bölümlerin birbirlerine bağlanmış olmasını bu eksikliklerin başında görür. Genel olarak Hamza Hakimzoda Niyoziy drama sahasına bir yenilik getirmiştir. 1917 yılından itibaren yeni Özbek dramasının yaratılmasında etkin rol almıştır. Hamza Hakimzoda Niyoziy, tiyatronun neredeyse her türünde kalem oynatmış, "Zengin ile Hizmetçi” adlı eseriyle dram türünde, "Ferace Sırları" adlı eseriyle trajedi türünde ve "Maysaranın İşi" adlı eseriyle de komedi türünde önemli sayılacak eserler yaratmıştır Bunların dışında "Kara Saç" isimli bir de operası bulunmaktadır (Mirzayev, 2005: 131).

Hamza Hakimzoda Niyoziy, "Zaharli Hayot" piyesinin sahnelenmesine yakından iştirak etmiştir. Rizayev’e göre yurtdışı seyahatlerinde Avrupa tiyatrosu hakkındaki bilgileri ile kendi tecrübelerini birleştirmiş olması muhtemeldir (1997: 81). Yönetmenlik ve oyunculuk tecrübesinin olması sebebiyle dikkat çeken eserler yaratmış, komedi ve dramalarında Özbek milli tefekkürünü açık şekilde göstermiştir (Tursunboyev, 2005: 33). Hamza Hakimzoda 20'li yıllarda "İftiracıların Cezası", "Yer Islahatı", "Mart Kurbanı Oynisa”, "Seçim Önünden” gibi küçük sahne eserleri de yazmıştır. Bu eserlerde kadın hakları ve yeni örf adetler yüceltilmiştir. 
Hamza’nın 1918 yılında yazdığı “Zengin ile Hizmetçi” piyesi Özbek edebiyatında ayrı bir yere sahiptir. Bu piyesin asıl metni kaybolmuştur. Günümüzdeki metin ise K. Yashin'in 1939 yılında yeniden yazdığı varyantıdır. Piyeste Özbek halkının yenileşme çabası gösterilmiştir. Ayrıca din adamlarının para uğruna zenginlere gösterdikleri farklı muamele de eleştirilmiştir. 1926 yılında yazdığ "Maysaranın İşi” piyesi satirik komedi türündedir. Folklorik pek çok malzemenin yer aldığı piyeste ahlaksız devlet memurlarına duyulan nefret dile getirilmiştir. Manevi bozukluk hicvedilmiş saf sevgi ve vefalı olma durumu yüceltilmiştir. $\mathrm{Bu}$ eserden yola çıkan bestekâr Sulaymon Yudakov, Moskova ve Leningrad tiyatrolarında sahnelenen "Maysara" isimli operayı bestelemiştir. Hamza Hakimzoda Niyoziy'nin 1927 yılında kaleme aldığı "Ferace Sırları" ise bir trajedi örneğidir. Kötü insanların kendi karanlık duygularını ve sırlarını saklamak maksadıyla feraceyi bir vasıta olarak kullanmaları anlatılmaktadır. Ayrıca feodal örf adetlerin ne denli gereksiz olduğunun anlatıldığı piyes devlet tiyatrolarında sahnelenmiştir (Rizayev, 1993: 85-92).

Önemli bir ceditçi olan, tiyatro alanındaki çalışmalarından dolayı Özbek edebiyatına ve tiyatrosuna önemli katkıları bulunan Hamza Hakimzoda Niyoziy'nin Taşkent'teki büyük tiyatro binasına ve pek çok yere adı verilmiştir (Vurgun, 2014: 225). Hamza Hakimzoda yeni Özbek edebiyatının şekillenmesi ve gelişmesinde önemli bir payı olan milliyetçi ve vatansever bir sanatçıdır. Hamza'nın sanat ve edebiyat alanındaki hizmetleri devlet tarafından ödüllendirilmiştir. 1926 yılında devlet aydınları arasında ilk sıralarda yer alıp "Özbekistan Devlet Sanatçısı" ünvanını almaya hak kazanmıştır. Eserleri birçok dilde sahnelenmiştir. Hamza Hakimzoda Niyoziy'nin eserleri genellikle günümüzde de Özbek halkına manevi destek vermekte gençlerin terbiyesinde önemli rol oynamaktadır (Mirzayev, 2005: 134-135).

Dört perde dört sahneden ibaret olan Zahorli Hayot Yohud Ishk Qurbonlari (Zehirli Hayat Yahut Aşk Kurbanları), Hamza Hakimzoda Niyoziy'nin eğitime verdiği önemi ve cahilliğin ne tür sorunlar doğuracağını anlattığı çok defa sahnelenmiş bir eserdir. İstemediği ve yaşı hayli büyük biriyle evlendirilen Maryam, kendini geliştirme ve sonraki nesillere de faydalı olma çabasında aydın bir genç kızdır. Zengin ve iyi eğitim görmüş olmasına rağmen mevcut düzene ayak uydurmak zorunda kalan Mahmud ise sonradan çok pişman olacağı bir adım atarak Maryam'in evlendirilmesine göz yumar. Maryam'in cahil ve görgüsüz ana babası, para için kızlarının bir adamın yedinci eşi olmasına razı gelir. Tüm bunlar geleceğe dair hayalleri olan pırıl pırıl bir genç kızın sonunu hazırlar, intiharına sebep olur. Hamza Hakimzoda, nesillerin böylesi geleneklerle heba edilmesini eleştirmiş, bundan sonrası için örnek teşkil etmesi adına bu piyesi kaleme almıştır.

\section{ZEHIRLİ HAYAT yahut AŞK KURBANLARI}

\section{Perdelik Trajedi}

\section{Y11 1916}

\section{Oyuncular}

Mirzo Hamdam: Orta boylu, hafif kır sakallı, kızıl yüzlü, vasat giyinen, 55 yaşlarında çok varlıklı olmasına rağmen ilim-irfandan uzak biri.

Abdiqodir: Mirzo Hamdam'in samimi arkadaşı, Mahmud'u seven, zamana ayak uyduran, uzun boylu, kirli sakallı, resmi giyinen biri.

Mahmud: İnce-uzun boylu, hoş bıyıklı, sakalsız, gür saçlı, gözlüklü, Avrupalı gibi giyinen, özel muallimler tarafından eğitilmiş, terbiye görmüş, Mirzo Hamdam'ın 18 yaşındaki tek oğlu. 
Maryam: Eski mekteplerde okumuş olsa da Mahmud'a yakın olmak için okuduğu roman, gazete, dergilerden ufku açılmış, Mahmud'u gerçekten seven, fakir bir ustanın 17 yaşındaki k1z1.

Müftü: Uzun cübbeli ve sarıklı kişi.

Sora: Maryam'in 35 yaşındaki annesi.

Zaynab: Maryam ile Mahmud arasında mektup taşıyan 60 yaşlarındaki ihtiyar kadın.

1. Perde

Mahmud'un Avrupaî şekilde döşenmiş odasında, bir tarafta içinde kitaplar ve haritalar olan bir dolap, çerçevelenmiş sinema afişleri, bir tarafta demir karyola, bir tarafta masa, üç dört tane tabure ve bir duvar saati.

Mahmud (Ceketini açıp cebinden bir mektup çıkardıktan sonra tekrar ilikleyerek kürsüye oturup mektubu açar.) : Bugün ne haber? Mektuba neler yazılmış acaba!

Tam okuduğu sırada kapıdan Abdiqodir girer.

Abdiqodir: Esselamün Aleyküm!

Mahmud (Mektubu göğsüne koyarak yürür) : Esselamün Aleyküm enişte, gelin, buyurun (yer göstererek) şöyle oturun, ben de tam sizi bekliyordum. (Kürsüye otururlar.)

Abdiqodir: (Fatiha okur) Eyvallah, berhudar ol...

Mahmud (Kalkarak) Hoş gördük.

Abdiqodir: Hoş bulduk. Ne var ne yok?

Mahmud: Güzel haberler sizde, enişte bey.

Abdiqodir: Şimdi bize düşen, getireceğimiz haber o kadar hoş olmasa da verilen cevabı her ne olursa olsun söylemektir. Suçlamayın.

Mahmud: Hayır muhterem! Niye suçlayayım. Haydi duyalım!

Abdiqodir: Şimdi, dün ben buradan çıkıp doğruca işe gittim. Beyefendi kendileri yalnızlarmış. Oturdum, çay ikram ettiler. Havadan sudan konuştuktan sonra lafi asıl meseleye getirdim. Elimden geldiğince anlatıp, eğer bu işler olmazsa Mahmud'un öfkelenip bir yerlere gitme ihtimali var, keşke biricik veliahtınızı memnun etseniz, o Maryam'i oğlunuza alsanız da gönlünü yapsanız, aksi halde ziyadesiyle kalbi kırılacak diye anlatılacak ne varsa anlattım. Ama siz huyunu biliyorsunuz, beyefendi hiç tepki vermedi.

Mahmud (Biraz değişerek): Sonuç olarak ne dediler?

Abdiqodir: Şimdi beyefendinin sözü şu ki, "Ben insanlar tarafından iyi, hoş bilinen şanlı şöhretli biriyim. Sadece Hokand'da değil Buhara'dan, Semerkand'tan Kaşgar'a kadar her yere sesimiz yetişir. Bir tanecik oğluma nasıl bir düğün yapacağım on, on beş yıldır aklımda. $\mathrm{Bu}$ ikinci düğünü doğru düzgün, bizden daha iyi ya da bizimle denk bir yerden biriyle yapayım ki, hem bize yakışsin hem de etraftan gelen eş dost münasip görsün. Şimdi böyle bir şöhretle gidip zavallı bir ustanın kızını alamam! İnsanlar bana ne der! Şimdi onların kafes gibi köhne bir evi vardır, düğün nerede olur? Peki, gelen eş dost nerede oturur? Rezil mi olalım! Oğlumuzu memnun edelim diye millete rezil olup, ayıplanmak daha mı iyi? İște bakın, okuyacağım dedi, siz biliyorsunuz altı yıldan beri ne kadar para harcadım, âlim olup verdiği fayda bu mu? (Eli ile işaret ederek) Asla, asla bu sözleri bir daha söylemeyin, üzülürüm. Sizin gibi yakın dostlarımdan duyacağım sözler bunlar mı? Çok ayıp!” dediler.

Mahmud: Peki, kendine bir kötülük yapacak demediniz mi?

Abdiqodir: Dedim, hiçbir laf bırakmadım hepsini söyledim. "Anası da razı değil, hısım akrabası da razı değil. Bu sözler imkânsız, kimsenin razı olmayacağı sözler. O kendisi de bilir. Ben ona yüzden fazla kız bulurum.” dediler. İki saat konuşup biraz yumuşayacağı sırada muhterem efendimizin Qosim isimli yardımcisı geldi. Belki o da bana katılır diye yeniden oturdum, yardımcısı da sorunca beyefendi kendileri cevap verdiler. Yardımcı, söz bittikten sonra "Beyefendi, siz haklısınız, size hiç uygun değil ama şu da var ki o kız müftü 
hazretlerine söz verilmiş. Şimdi müftü hazretleri talebe toplamaktan döndüklerinde belki bu ay içinde düğün de olabilir" deyiverdi. Beyefendi "Eğer sizin lafınıza uysak rezil oluruz" diye konuşarak beni utandırdılar. Artık size düşen bir laf kalmadı, muhterem efendiden sonra konu kapand1.

Mahmud: (Şaşırarak) Müftü hazretlerinin eşi var mıydı?

Abdiqodir: Var, bir tane değil, altı tane. Altıarıkı1 ${ }^{2}$ olan hanımı öldü. Şimdi beş tane var.

Mahmud: Altı taneymiş, bunu ne yapacaklar şimdi?

Abdiqodir: Ey şehzadem! Siz daha toysunuz, bedava nevale olduktan sonra kim almaz sizce. Eskiden böyle muhteremlerden iş geçmiş olurdu! Yoksa bir ayağı çukurda birine kim verir genç hatunu!

Mahmud yerinden kalkar.

Nereye gidiyorsunuz?

Mahmud: Lafa dalıp kaldık. Çay koyayım.

Abdiqodir: Yok efendim, çaya vaktim yok. Başka zaman yine gelirim. (Kalkar).

Mahmud: (Gönülsüz) Keşke çay içip gitseydiniz ya!

Abdiqodir: Keşke ama çay içmediğim yer mi, teşekkürler. (Çıkar)

Mahmud: (Uğurlayarak) Allahaısmarladık öyleyse.

Abdiqodir gider. Mahmud ortada biraz durup kalır, kürsüyü masanın yanına çekip sahneye bakarak oturur. İç çekerek kalkıp yürür, sonra yeniden oturur. Elini dizlerine koyar.

Ah cehalet, bilgisiz zenginlik! (Mektubu alır, açıp bakar, ayağa kalkar, dışarıya seslenir, yeniden gelip oturur.) Tek bir erkek dahi gelse yok deyin. (Peki, deyip giderler. Mahmud dizlerine vurur.) Ey cahil analar, cahil babalar! Ben ne yapayım arzu hevesi? Arzu heves kendi isteğimden başka bir şey değil.

\section{Biraz sessiz kalıp kalkar. Bu arada Maryam gelip kapıdan içeri doğru bakar. Mahmud habersizdir.}

Ben arzu hevesi ne yapayım, sevdiğim olmadıktan sonra bin arzu bir kuruştur bana. Belki de zehirdir, ölümdür bana. (Biraz bekler.) Ben bey kızını ne yapayım! Evet, tam kendimi cehaletten kurtardığım vakit yine bir cahile, bir geri kafalıya hayat arkadaşı mı olayım? Bana hayat gerek. Hayat için gönlümdeki amaç gerek. $\mathrm{O}$ amaç ise (kafasını sallayarak) Maryam'dan başkası değil, olamaz.

Meslekte, fikirde, ilimde en değerli varlığım olan Maryam gibi gerçekten gönlümdeki sevgili dururken bana dünyanın tüm arzularını, peri gibi bey kızlarını arzulamak haram! Haram! Ah, onun bana tatlı tatlı yazdığı mektuplar... (yürür, masa çekmecesinden bir mektup getirip açar.) İşte, bunu yazmış, yazdığı ilk mektup bu (ilk mektubu okur): "Biricik aşkım, sevgili Mahmud! Ben size ne kadar sevgi beslediğimi yazmayacağım, vaktinizi çalmamak için sözü kısa tutarak maksadıma geçiyorum. Doğru söylemek gerekirse, ben eski usul mekteplerde tahsil gördüm ancak tüm insan ve hayat meselelerini sizin merhametiniz ve manevi yardımlarınız sayesinde öğrendim. Sizden ikinci isteğim, derhal mücadeleye başlamak. El ele verelim, siz güneş ben ay olup karanlık vatanımızı aydınlatalım. Siz erkeklerin durumunu yazın ben de mazlum ailelerin durumlarını yazayım, herkesi bilgilendirelim. Siz tüccar olsanız da gerçek maksadınız olan kız okulunu açalım. Ben manevi yönden destekleyeyim, siz de maddi yönden destekleyin. Kıymet görmeyen kız kardeşlerimizi ilim sayesinde kurtaralım. Gerçekleştirelim ki, gelecekteki evlatlarımızın mezarımıza kırmızı beyaz çiçekler bırakarak dualarını alacak şekilde bir hizmet ortaya koymuş olalım..." (Mahmud dizlerine sertçe vurarak) Ah işte bu mektup nasıl güzel bir hayat veriyor. Ben hangi vicdanla bundan yüzümü çevireyim? Bu mektup bana bin bey kızından daha kıymetli olmaz mı? (Mahmud ilk mektubu

\footnotetext{
${ }^{2}$ Özbekistan Cumhuriyeti'nin Fergana iline ait ilçesi.
} 
koynuna koyup, ikinci mektubu açıp bakar.) Maryam beklemekteyken ben durup kalamam ki! (Mektupları bağrına basıp arkasına baktığı sırada Maryam kapıyı açar, bakar, Mahmud selam ile elini öpüp) Buyrun, hanımefendi! (Alıp kürsüye geçirir) Hanımefendi, ben kapıya birini koyup gözcülük yaptırayım.

Maryam: (Mahmud ellerinden tutarak) Ben geleli çok oldu. Hemen dönmem lazım.

Mahmud: Peki hanımefendi! Ne olur ne olmaz, kimse gelmesin. (Çıkıp gider).

Maryam: (Kitapları göstererek) Ah tatlı hayat, gerçek yoldaş, keşke herkes böyle kâmil, çok bilgili insan olsa. Zavallı, biçareyim. (Yürüyüp çıkar)

\section{Mahmud gelir.}

Mahmud: (Kürsüye buyur edip) Hanımefendiciğim, neden habersizce geldiniz?

Maryam: (Oturarak) Hiç teklife gerek duymadan muhabbete geldim. Bir süredir korkunç bir rüya görüyorum. Meraklanıp bir firsat bularak görmek istedim. Zahmet verdiysem kusura bakmayın

Mahmud: (Kalkar) Baş üstüne hanımefendi. Ne zahmeti, rica ederim?! Rüyaların benim için önemi yok, ancak...(sessizlik)

Maryam: (Çekinerek) Efendim! Sustunuz?!

Mahmud: (Mendil alıp göz yalını silerek) Hanımefendiciğim...İkimize de eziyet olacağa benziyor!

Maryam: (Biraz çekinerek Mahmud'un elini tutup okşayarak) Ne, ne? Acı!

Mahmud: (Elini tutarak) Bunu size söylemeye dilim varmaz!

Maryam: (Yine yalvararak) Duyduğum sözlerden değil, dedim ya! Gördügüm rüyalardan mutsuz oldum. Söyleyin haber neymiş? Ne oldu?

Mahmud: Bunu kendim söylemeye mecburum ancak gönlüm razı değil.

Maryam: (Ağlamaklı) Hayır, söyleyin!

Mahmud: Ben dün birini babama yolladım. Onun söylediğine göre babam kabul etmemiş. Belki şimdi, o kabul etmese de her zorluğun bir çaresi vardır. Şimdi sizinle ilgili bir sıkıntı var ki, her şeyden daha ağır.

Maryam: Hayrola, neymiş?

Mahmud: Anne babanız sizi muhterem efendiye uygun görmüşler. (Maryam korkar). Sanırım bu aylarda düğününüz olacakmış. (Maryam yine ürküp düşer, alnını tutar) Şimdi ben bu sebeple derin düşüncelere daldım.

Maryam: (Biraz sonra) Efendim, sizsiz dünyada bir gün kalmak bana ölümden beter! Ben (ağlayarak) hiçbir zaman kabul etmem, elimden geldiği kadar kendimi o zalimden saklarım. Canım, söz sizde, kendi iradenizle karar verirseniz elbette ben de elimden geleni yaparım (ağlar).

Mahmud: Canım, ben sizden de fazla, bu dünyada sizsiz kalamam. Buğum sizden ayrılmam gerektiğinde hemen aynı gün kendimi helak ederim. Canım, bana sizsiz hayat zehirdir. Bana güveniniz ki bugünden itibaren harekete geçiyorum. Siz de mutlaka o taraftan mani olursanız yeterli.

Maryam: (Mahmud'un elini tutup daha yakına gelerek) Allah'tan bir mani olmazsa başka bir memlekete kaçmak mümkün, değil mi? 
Mahmud - Elbette mümkün canım, ama iş olmadan çaresiz kalırız. (Bu sırada "patron geldi" diye ses gelir, Mahmud telaşlanarak) Şimdi...(Maryam kalkar) Kusura bakmayınız, habersiz gelmeniz biraz zamansiz oldu.

Maryam (Mahmud'un elini tutup göğsüne koyarak) - Yine beni fakir diyerek dişlamayınız canım. Fakirliği ben seçmedim.

Mahmud - Ah canım! Beni ateşte yakmayınız. Ben o vicdansızlardan değilim (Elini alır, öper).

Maryam (Örtüsünü örtüp) - Beni unutmayın! Duygularımla oynamayın! (Ağlar)

Mahmud - Canım, asla unutmam, siz merak etmeyin (Alnını sıvazlar).

Maryam (Kapı önüne varır) - Canım, ben her daim ümidimi koruyacağım. Evvela merhametli, iradeli olun, dünyaya aldanmayın...

Mahmud (Elini öpüp) - Canım, siz unutsanız da ben asla unutmayacağım.

\section{Birlikte çıkarlar. Perde kapanır.}

\section{Perde}

Maryam zorla müftü hazretleriyle evlendirildikten üç dört gün sonra.. Müftü hazretleri içerde dururken görünen yer onun kilerinden ibaret.. Ortadan içeri doğru Maryam'in yanında bir kapı var.

Maryam (Zarif bir şekilde giyinmiş, yalın ayak, kapıdan hızla çıkarak, aceleyle) - Ya Rabbi! (Kapıya bakarak) Mahmud, neredesin canım! Halimi gör! Nerede verdiğin sözler! Ey Allah'1m, çare ver. (Ağlar) Yardım et!

Müftü (Yakına gelerek) - Maryam! Size ne oldu? Benden neden kaçıyorsunuz!?

Maryam (Küçük odanın bir tarafina kaçıp) - Yok olun! Yok olun! Hain, insafsız, kalpsiz, zalim! Gözüme görünmeyin!

Müftü (O an sakalını sıvazlayarak başını sallayıp) - Bir can derdi! (Daha yakına gelerek) Son zamanlarda neden böyle yapıyorsunuz? (Eli ile göstererek) Ben insanım! Vahşi değilim ki!? Bana bu yaptığınız ne şimdi, benden kaçıyorsunuz. Kalkın! Eve girin! Böyle yapmayın, ben mutsuz oluyorum.

Maryam (Öfkeyle) - Gidin, girmeyeceğim dedim ya!

Müftü (Öfkeyle yanına gelip, eğilip elini sallayarak) - Evet, kalk diyorum! Daha namaz kılacağım!

Maryam (Acıyla hıçkırarak, ağlamaklı) - Kalkmayacağım! Daha fazla yaklaşmayın! Namaz kılacaksanız k1lın! Ölmek istiyorum, ölmeye razıyım. Bundan sonra ölüm benim için daha iyi! Ah, ecel! Keşke şimdi canım çıksa böyle bir imansızın elinden kurtulsam! Ölüm (Ağlar).

Müftü - İstediğin kocaysa işte ben! Başka isteğin ne? Yoksa başka derdin mi var?

Maryam (Hıçkırıklarla ağlayarak) - Var, var! İsteğim var, senin gibi ihtiyarı kendime koca yapmayacağım diyorum ya, daha ne?

Müftü (Parmağını 1sırıp, yavaşça omzuna elini koyup yine acıyla) - Kim o istediğin, söyle!

Maryam - Var dedim, var! Söyleyip ne yapayım, var!

Müftü - Sakin ol, şimdi o istediğinden ümidini kes!

Maryam - Ümitsiz şeytandır!.. Ben ümidimi kesmeyeceğim! 
Müftü (Öfkeyle yanına gidip, eğilerek, elini sallayıp) - Senin benden kurtulmak gibi bir ümidin mi var?

Maryam - Var elbette, her taraftan var!

Müftü - Kurtuluş yolunu nasıl bulacaksın?

Maryam - İnşaallah bulacağım! Şimdi olmasa da ilerde bir gün bulacağım!

Müftü - Sen beni ne diye düşünüyorsun o halde?

Maryam - Bir imansı, Allah'tan habersiz ihtiyarın tekisin! Nesin?

Müftü - Estagfurullah! Ben seni kolay mı elde ettim? (Daha yakına gelip) İyilikle kalk diyorum! (Elinden çekerek)

Maryam (Elini itip, hıçkırıklarla ağlayarak) - O elini uzak tut! İmansız! Yanıma gelme, insafsiz, utanmaz! (Ağlar)

Müftü (Öfkeyle) - Ne yapıyorsun burada?

Maryam - Kendimi öldüreceğim, anlıyor musun! Sana esir olacağıma ölmek bin kat iyi! Burada öleceğim! Girmeyeceğim!

Müftü (Yine öfkelenip) - Mutsuz, dışlanmış olursun!

Maryam - Allah'ın izniyle hiçbir şey olmam! Elinden ne geliyorsa yap! (Ağlar)

Müftü - Sen yolunu şaşırmışsın! Seni okumuş diye söylediler, hiçbir şey bildiğin yok! Beni tanıyor musun? (Elini sallayıp acı ile titrer) Beni tanıyor musun? Ben müftü hazretleriyim! Büyügünden küçüğüne, zengininden fakirine beni kim görse ayağa kalkar, benim çiğnediğimi yüzlerine sürmekten gurur duyarlar, sense bana saygı duymaktan çok lafimı kesiyorsun, dalga geçiyorsun. Genç diye affetsem asi oluyorsun!

Maryam - Ey bilgisiz müftü! Sakin ol, affetmek Allah'a, asi olmak kula hastır. Kula kim vermiş affetmeyi! Ben gayet iyi eğitimliyim, kendime göre din, diyaneti senden iyi bilirim.

Müftü - Konuşma zavallı! Yine başladı! Benim evdeki beş karımın hangi biri senden çirkin? Onlar senden daha zengin adamların kızı. Sen zavallı bir kunduracının kızısın. Şu zavallı halinle bu kadar nazlanıyorsun! Benim verdiğim yağ, pirinç ile anan baban yemek gördü! (Boynunu gösterip) Benim paramla boynun inci kolye gördü! Hâlâ niye naz yapıyorsun?

Maryam (Kederle inci kolyeyi kırıp yere atarak) - Al eşyalarını, benim mücevherim var, kuvvetim var, benim gözümde yok böyle şeyler. Sen söyledin, benim anamla babam cahil, senin gibi zalim, acımasız. Ben böyle zehirli güçten, işe yaramaz hayattan bıktım. Senin gibi utanmaz, inançsız, münafık bir ihtiyarla yaşamaktansa ölüm daha iyi! Kara toprağın altı daha iyi! Ben ne yapayım senin zenginliğini, halin bu mu? Yaşamak gerekmez, öldür! (Ellerini açarak, titreyip ağlayarak) Ah zalim felek!

Müftü (Öfkeyle) - Şeriat uygun görürse ne yapacaksın?

Maryam - Şeriat benim gibi bir mazlumu senin gibi dünden bugüne ölüm yağdıran, insafsız bir ihtiyara asla uygun görmez. Şeriat da önce benim kabul etmemi uygun görür. Nikâh tarafların kabul etmesiyle helal olur. Ben kabul etmezsem nikâh haramdır. Şeriata istinaden ben kabul etmiyorum! (Ağlayarak) İmdat!

Müftü - Anan baban verdi. Şeriata göre imam, nikâhı kıydı. Onlar senin gibi bilmiyor muydu? 
Maryam - Dedim ya, anam babam cahil, bu dünyaya düşkün insanlar. İmamlar da kötürüm. Şeriatın başındakilere parayla her şey yaptırılır. Tek takva sahibi müftü sen misin, sen mi!? Başkası ne olur şimdi!...

Müftü (Sonunda sinirle) - Ben seninle bu konuda tartışacak değilim, kalk diyorum!

Maryam (Öfkeyle) - Ben de seninle bir hayat paylaşacak değilim. Kalkmayacağım!

Müftü (Öfkeyle) - Niçin geldin?

Maryam (Ağlayarak) - Mecburiyet getirdi beni, cehalet getirdi, zulüm, zulüm getirdi.

Müftü (Elinden çekip) - Otur diyorum uğursuz!

Maryam (Elini silkip evin dışına doğru kaçıp ağlayarak) - Kurtarın zalimin elinden!

Müftü (Kapı önüne gelip biraz bekleyerek) - Ha uğursuz!

Maryam - Doğru ben uğursuzum, ben kadersizim! Kadersiz olmasam senin gibi bir zalimin eline düşmezdim. (Gökyüzüne bakarak) Ya rabbim, zalimin elinden kurtar (Ağlayarak) ya da ecel ver!

Müftü (Sakalını sıvazlayarak) - Ben önce sükûneti sağlayıp sana münasip bir ceza vermezsem olmazmış! (Çıkıp gider)

Maryam (Arkasından bağırarak) - Ver, ver cezamı! Öldür, öldür, bıçak alıp şehit et! Ya rabbi, ben mazlum, ben aciz, ben kolu kanadı kırılmış, anası babası tarafindan zalim dünyaya satılmış... Yırtıcı bir hayvana esirim. Zalimin elinden kurtar. (Yine biraz durup) Mahmud neredesin! Halimi gör! Merhametsizlik ettin, vefasızlık ettin! Vaadlerin neydi! Bu zalime esir ettin! (Biraz düşünüp) Hayır, onun da suçu yok. (Eli ile göstererek) Beni, beni! Bu kem talihimde suç! Hayır, şimdi beni bu münafik, bu lanetli adam rahat bırakmaz. Şimdi hemen bundan kurtulmanın yolunu bulmalıyım. Önceden almayan Mahmud'un babası şimdi iyice almaz. Bir ilaçla bu zalimden kurtulmak için kendimi öldürmekten başka çare yok! Bu zehirli hayattansa ölüm daha iyi! (Düşünerek) şimdi burada hiç çarem yok, evime kaçmam gerek bir başıma... içerim, iki üç gün yatarım, şayet kurtulursam gece de olsa kaçmam gerek.

Müftü girer, elinde kırbaç, öfke ile üzerine doğru yürüyerek.

Müftü - Yürü, gir içeriye ahmak!

Maryam - Kırbaçla çabuk ölmem. Sadece eziyet etmiş olursun. Balta, keser alıp kesip atmak daha basit. Tek seferde öldür!

Müftü - Ben kasap değilim, ben cani değilim!

Maryam - Canilik bundan daha iyidir.

Müftü - Ben kimi öldürdüm ki seni öldüreyim!?

Maryam - Tek yapmadığın adam öldürmekti, onu da yap şimdi!

Müftü (Kırbaç sapını başına savurup öfke ile) - Ben hazretim hazret! Eşkıya değilim!

Maryam - Eşkıyadan farkın yok.

Müftü - Estağfurullah estağfurullah! Şimdi bütün bedenini yararım!

Maryam - Yap bildiğini!

Müftü - Genç bedenine de mi acımazsın?!

Maryam - Senin gibi asil efendi, müşfik anam babam genç yaşıma acımamış, ben ne diye acıyayım! 
Müftü (Kızgınlıkla elinden çekip) - İyilikle gir!

Maryam (Elini çekip, ayrılıp, dirseğiyle iterek) - Kurtarın zalimden! (Kaçar)

Müftü (Yere yıkılıp, arkasından bağırarak) Bekle melun, ahmak, bekle!

Koşarak çıkıp gider. Perde kapanır.

\section{Perde}

Sade bir zevkle döşenmiş bir ev. Onun bir tarafinda büyük bir sandık, onun üzerinde yanına dört beş adet kitap konulmuş küçük bir sandlk. Onun bir tarafinda sıradan bir kanepe, üstünde Maryam, durumu ă̆ır bir halde ağlayarak yatar. Bu ev Maryam'in evidir. Zehir içtikten sonraki gün Sora yanı başında ağlayarak otururken perde açılır.

Maryam (Halsiz bir halde Sora'ya) - Anacığım, lütfen çok ağlamayın! Duymak istemiyorum. Bütün bu işlere siz sebep oldunuz. Dünyayı sevdiniz ama canınızdan bir parçayı, evladınızı sevmediniz, her şeye göz yumdunuz, bugünkü halimi düşünmediniz. Şimdi ne için ağliyorsunuz...

Sora (Başını okşayıp, ağlayarak) - Canım yavrum, benim rızam yoktu, baban sebep oldu, beni kendi halime bırakmadı, ben nasıl edeyim? Bu hallere gelmene nasıl razı olurum canım kızım. Nenen ölsün! (Saçlarının her tarafını okşayarak) Birincisi şu ki Allah'ın takdiri, iradesi. İkincisi babanın isteği... Ben sana nasıl kıyarım.

Maryam - Elbette, en çok siz sebep oldunuz. Çünkü biliyordunuz ki aile hayatında böyle sıkıntılı günler, zorlu haller var, belki sizin başınızdan geçtiği için endişe etmiş olabilirsiniz! Siz hayır diye direnseydiniz, babam da biraz kabul ederdi. Halbuki siz daha ziyade hazret efendinin servetine aldanıp hareket ettiniz. Hakiki servetinizden ayrılmak pahasına böyle bir duruma düştünüz. Şimdi servet mi başka bir şey mi daha iyi görürsünüz.

Sora (Ağlar) - Doğru canım kızım. Her ne olduysa biz sebep olduk. Şimdi dert etme. İyileştikten sonra konuşuruz (Alnını siler).

Maryam - Durun, çok ağlamayın. Yüreğim yandı. Biraz soğuk su bulup getirtin. Ondan sonra Zaynab halamı da çağırın, nasıl olsa gidiyorum, biraz başımda dursun.

Sora ağlayarak çıkar. Maryam üstündeki yorganını göğsüne kadar açarak örgülerini göğsünün üzerine düşürür, başını örtüp hafif kaldırarak, dudaklarını yalayıp, derin nefes alır.

Ah, ah iyileşemiyorum. Ah evlat kıymeti bilmeyen atalar! (Saçlarını göstererek) Kendi baharımı yaşayamadan bu kara sümbüllerimi erkenden toprağa koymayın. (Ellerini gösterip) Benim gibi cehalette kalmış kız kardeşlerime vakti gelince kalemle hizmet edeyim diyen nazik ellerimi bağlayıp aydınlık dünyaya doymamış yüzümü gözlerimi kefene sarıp da kara toprağa koymayın. Ah felek! Zalim felek! Ben ne günah işledim! Dünyada en tatlı zamanlardan mahrum ettin,ah,... (Düşer)

\section{Zaynab girer.}

Zaynab - (Maryam'ın yanına gelip yüzünden öperek gözlerine bakar) Canım Maryam, canım yavrum! Ben geldim, halan kurban olsun, aç gözünü, nasılsın?

Maryam (Yüzüne doğru bakıp ağlayarak) - Gelin anacığım. Çabuk gelmediniz, ben sizi gördüğümde sevgili Mahmud'umu görmüş gibi oluyorum. Çünkü sizden merhametsiz Mahmud'un kokusu geliyor. Ne olurdu ki birkaç saat kalan ömrümde Mahmud vefasızlık yapmasa. Siz yanımda kalsanız... Size bakarak can vereceğimi anlamazdım halacı̆̆ım! Siz hepsinden haberdarsinı!

Zaynab (Yüzünden, ellerinden öpüp, alnını sıvazlayıp) - Vay yavrum Maryam, ben seni nasıl hor görürüm yavrum. Size ne oldu? Böyle ümitsiz sözler söyleme hanım kızım. (Maryam'in 
gözyaşlarını temizleyip) Yüzünün rengi gecekinden daha iyice, tez zamanda düzelirsiniz canım yavrum.

Maryam (Başını kaldırıp) - Anacı̆̆ım, benden hayat ümidi yok. (Ayağını göstererek) İşte ayağıma dokunun, hissizleşmiş. Bütün canım göğsüme toplanmış. (Başını sallayarak) Hareket etmeye zerre mecalim yok fakat şefkatsiz Mahmud'u görürüm diye can havliyle bekliyorum. Şimdi... Bu dünyada tek bir isteğim var... Sadece Mahmud'u bir görmek, en zor zamanlarımda veda edip helallik istemek, istemek ve de kulağına iki çift laf söylemek... Öyle ki gözüm arkada kalmasın halacığım... (Yüzünden öpüp, sıvazlayıp) Bu zalim vefasız felekten yüreğim soğudu halacı̆̆ım! Mahmud'u görmek mümkün olur mu ki?

Zaynab (Ağlayarak, alnını sıvazlayıp) - Canım yavrum, Mahmud sizden de beter üzülmüş. Her gün dört-beş kez gelip benden sizi sorup gidiyor. Karşınıza çıkmak için anne-babanızdan çekiniyor. İşte şimdi de gelmişti. (Koynundan iki tane çiçek, bir tane mektup çıkarıp vererek) işte bunu size vermemi istedi. O sırada büyükanneniz çağırdı.

Maryam (Yıkılmış bir biçimde alıp, can-1 gönülden göğsüne bastırıp, gözlerine sürerek) - Ah Mahmud, merhametin varmış, şefkatin varmış! Beni yoklarmışsın, hayalinde varmışım, hayret! $\mathrm{Bu}$ dünyada on-on beş dakikalık ömrüm kaldı ama bin yıllık ömrüm varmış gibi ümidim var artık! (Kendini bırakır, çiçekler yuvarlanır)

Zaynab (Çiçek ve mektubu alıp yastığın altına koyup Maryam'ın başını tutarak) - Canım yavrum, büykannenize söyleyip getirttiğimize biraz da olsa sevinseniz.

Maryam (Biraz sonra Zaynab'in ellerini tutup yalvararak) - Canım halacığım! Ben şu anda hem size hem Mahmud'a hem de ana-babama yarım saatlik kıymetli bir misafirim! Bu garip evladınızı memnun edip gözü arkada kalmadan göçmesini sağlasanız, ahiretlik validem olurdunuz...

Zaynab (Yerinden kalkıp) - Ben Sora’ya söyleyeyim öyleyse.

Maryam (Eli ile göstererek) Önce şu sandıkta Mahmud'un gönderdiği üç dört mektup, iki üç kitap var. Başucuma bırakın. Geldiğinde kendisine vereyim.

\section{Zaynab alıp başının altına koyup gider.}

Ah ya rabbi! Keşke görebilsem...

\section{Zaynab ile Sora girer, Sora'nın elinde soğuk su.}

Sora (Suyu alarak) - Al canım kızım.

Maryam (Başını sallayarak) - İçmeyeceğim.

Sora (Üzgün bir biçimde kaseyi yere koyarak) - Maryam, şimdi halan Mahmud'u çağırıp gelsin mi?

Maryam (Yalvararak) - Keşke merhamet etseniz...

Sora (Zaynab'a bakarak) - Öyleyse babası gelmeden çabuk çağırıp gelin.

Zaynab çıkıp gider.

(Minderleri düzelterek) Ben öyleyse yemek hazırlayayım kızım. (Çıkar)

Maryam (Kendi kendini kaldırayım derken kaldıramaz, boynunu büküp) Vay, göğsümden kuvvet gitti. Kımıldayabilmem ancak bu kadar. Görebilsem iyi olurdu. (Yaka düğmelerini açayım derken açamayıp) Vay işte, elim de güçten düştü. Ya Rabbi... (Mektubu bağrına basıp) Gözüm donuklaşmış, Mahmud çabuk gel! Belki göremeyebilirim. Belki 
tanıyamayabilirim. Ah, (dudaklarını yalarken, nefesi tıkanıp) ah babam, acımasız babam... Galiba göremeyeceğim.

Kapı açılır, Mahmud girer.

Mahmud (Maryam'i bu halde görür görmez kendini üstüne atarak) - Ah Maryam, güzel canım! (Ceketini çıkarıp başını kucağına alarak) Maryam, güzel canım! (Yanaklarını okşayıp) zalimin geldi, Maryam, Maryam!

Maryam (Mahmud'un boynuna elini koyup) - Şükür, şükür!.. Gördüm, görebildim Mahmud. Allah hayır versin (İşaret ederek). Başımı daha yukarı kaldır (Yukarı kaldırır). Gözüm donup kald1.

Mahmud (Ellerini tutup öperek) Canım, benim ben... Seni bu hallere koyan hamiyyetsiz insan ben (ağlayarak).

Maryam - Ben sizden razıyım Mahmud. Sizde hiç kusur yok. Şimdi benden razı olun. İsteğim kendi kulağımla senin razı olduğunu işitmek ve bir de emanet sözünü kendi ağzımla söylemekti.

Mahmud - Maryam, böyle ümitsiz sözler söyleyerek yüreğimi yakma canım. Ben sensiz dünyada duramam, durmam canım!

Maryam (Dudak büküp başını sallayarak) - Misafirim ben Mahmud! Benden ümidi kes, bu en son görüşmemiz canım! Benim senden bir isteğim var, evvela bu dünyadan göçtüm diye beni unutma. (Parmağındaki yüzüğünü alıp Mahmud'un eline bırakarak) Canım, işte bu daima elinde dursun, eğer beni unutmazsan bazı zamanlar mezarıma gel, gelişinle ruhumu memnun edip dön... ( Mektupları göstererek) Bunları al, tebrik mektuplarındı, öldükten sonra halimi yaz, yadigar kalsın... Benden sonra kendini helak etme. Ben bu dünyadan genç ayrıldım, sen uzun yaşa... Beni unutma... Allahaısmarladık, hoşça kal! Ah cehalet, zehirli hayat! (Yıkılır)

Mahmud (Ağlayarak boynuna sarılıp) Maryam! Maryam! (Feryat ederken bir taraftan Sora, Zaynab kendi kendini Maryam’in üzerine atarak kucaklarlar) Maryam, anan ölsün!

Perde kapanır.

4. Perde

Kabristandan bir görüntü olup, Maryam'ın mezarından ibarettir ${ }^{3}$. Perde açılır. Bir taraftan Mahmud girer. Başında mavi sarık, bir elinde palto, bir elinde çiçekler deli gibi bir halde...

Mahmud (Mezara bakarak saygıyla) - Esselamü Aleyküm ya Ruh-1 Maryam. (çiçekleri gösterip)

$\mathrm{Bu}$ benim size hediyem canım! (Paltosunu bir tarafa bırakarak çiçeklerin bağını açıp) Mezarınıza saçmak için getirdim! Canım Maryam (Kabrinin üstüne saçarak) Güzel Maryam! (Biraz bekleyip kalkar) Nasıl yakıştı, canım Maryam. (Kollarını arkada kavuşturup öne doğru seyirterek ağlamaklı bir şekilde) Canım Maryam. Zalimin geldi. Şirin dünyadan göçmenin tek sebebi, vefasızın geldi. Hatırlıyor musun? Ben çok özledim, sen özlemedin mi? (Dizlerine vurarak) Bitmez mi! Bitmedi bu dargınlık! (Biraz korkarak) Ya Allah... (Maryam'in mezarına kapanarak ağlayıp sızlar) Canım Maryam, güzel Maryam! Sana zulmeden bir ben miyim? (Eliyle sayarak) Benim cahil babam, senin cahil anan baban, benim cahil anam, sebep olan dört kişi! Ben her dediğini kabul ettim. Senin böyle olmana anan baban sebep oldu!

\footnotetext{
${ }^{3}$ Bu perdede (Kabristan manzarası) mümkün olursa sahne (oynanılan yer) dışındaki ışıkları açmaları sahnenin sadece iki ya da bir yanından öndeki ışığı açık tutmaları gerekir. Yani sahne ne kadar karanlık olursa o kadar inandırıcı olacak ve oyuncularımız doğaçlama yapabilecek.
} 
Bende o kadar günah yok ki! Yok, yok canım yok. Affet, günah sadece ana-babalarda da değil. (Öfkeyle elini sallayıp) Bu olanlar cehaletten, gafletten, bilgisizlikten... bu nasıl cahil bir zaman, nasıl korkunç bir zaman!.. İnsanlığı, vicdanı, adaleti, şefkati dahası evladını parayla sattıran zaman! Ben yaşamam, sensiz dünyada bir gün durmam, söylemiştim. Ben insanım, vefalıyım. (Korkuyla, şaşkın bir ifadeyle çantasından tabancasını alıp) Maryam işte hazırım, yanına geleceğim emin ol, kıyamet günü ikimiz el ele tutuşup Cenab-1 Hak ve Resulünün huzurunda bu şeriat hainlerini beraber dava edeceğiz. Canım Maryam! (Tabancayı hızla göğsüne dayayıp ) Ben sensiz yaşamam, kendi güzelliğim olmayınca dünya haram...

Ah cehalet!... Gaflet! Feryad, zehirli hayat! Sikar. Yıkılır. Bir taraftan fanus ile Mahmud'un anası gelerek çı̆̆lıkla yüzünü yırtar. Perde kapanır.

\section{Kaynakça}

Baydemir, H. (2011). Özbekistan'da geleneksel tiyatronun bir şubesi: Maskarabazlık ve Kızıkç1l1k. Turkish Studies, Volume 6/1, winter 2011, 763-777.

Karakaş, Ş. (2001). Türkistan'da ilk tiyatro faaliyetleri ve Pederkuş piyesi. KırgızistanTürkiye Manas Üniversitesi sosyal Bilimler Dergisi, 2, 162-185.

Mirzayev, S.; Shermuhammedov, S. (1993). Hozirgi Zamon O'zbek adabiyeti tarixi. Taşkent: O'zbekiston.

Mirzayev, S. (2005). XX. Asr O’zbek adabiyoti, Taşkent: Yangi Asr Avlodi.

Rizayev, Sh. (1997). Jadid draması. Taşkent: Shark Nashriyet-Matbaa Koncherniyasining Bosh Tahririyati.

Tursunboyev, S. (2005). Teatr tarixi. Taşkent: Bilim.

Vurgun Yılmaz, S. (2014). Türkistan'da Ceditçilik hareketinin etkisinde tiyatro. Trakya Üniversitesi Sosyal Bilimler dergisi, Aralık, c.16, s.2, 219-232. 